\title{
W sprawie konieczności zachowania przedludzkich systemów komunikacyjnych (bezjęzykowych) w kontekście zachowania bioróżnorodności
}

\author{
Concerning the necessity of the preservation \\ of prehuman communication systems (languageless) \\ in the context of the preservation of biodiversity
}

\begin{abstract}
On the basis of the existing and unquestioned linguistic stance, a division of all the living creatures inhabiting the Earth into those which do not have language (i.e. prehuman and languageless) and those who have language (i.e. the genus Homo sapiens) is postulated. The paper briefly discusses a rich diversity of communication modes occurring in the domain of the prehuman communication systems, such as the auditory, visual, tactile, olfactory, electric, thermal, and seismic ones, with appropriate graphic illustrations. Furthermore, on the basis of the phenomenon of the observable shrinking of this diversity and the key position of the human species, it postulates the necessity of preserving this diversity in the context of biodiversity. This major postulate is in accord with the need to intensify attempts to preserve biodiversity as well as preserve the remaining diversity on the level of the prehuman communication systems as a major challenge of modern humanity. In this context, the human species is considered here as the species of the 'overseers' and 'archivers' of all the existing communication systems existing on the Earth as the carrier of the tree of life.
\end{abstract}

Keywords: universal communication space, prehuman communication systems (languageless), biodiversity, preservation of biodiversity, indexical systems, symbolic system, communication mode, communication order

Stanisław Puppel, Uniwersytet im. Adama Mickiewicza w Poznaniu, Poznań - Polska, spuppel@ amu.edu.pl, ORCID ID: https://orcid.org/0000-0002-1203-9282

\section{Wstęp}

Na gruncie językoznawstwa podział wszystkich istot żywych zamieszkujących ziemię na posiadające język, czyli człowieka (Homo sapiens), i go nieposiadające, czyli wszystkie inne poprzedzające (przedludzkie) gatunki biologiczne, nie wymaga dalszych komentarzy. Taki podział przyjęty został przez językoznaw- 
stwo, w tym językoznawstwo ogólne, językoznawstwo antropologiczne, biolingwistykę i językoznawstwo ewolucyjne. Zatem człowiek odróżniony został od innych gatunków na linii 'język - brak języka (bezjęzykowość)', gdzie przez 'język' rozumie się złożony wielopiętrowy system symbolicznej reprezentacji rzeczywistości, wykształcony filogenetycznie (ewolucyjnie) i przekazywany ontogenetycznie i międzypokoleniowo. Natomiast zjawisko 'bezjęzykowości’ odnosi się do innych systemów komunikacyjnych, będących w posiadaniu pozostałych, a więc przedludzkich, gatunków biologicznych (zob. np. Sebeok; Hauser). Są to systemy przedsymboliczne i przede wszystkim oparte na wskaźnikowości (zob. np. Nöth) wykorzystującej prosty i powszechny mechanizm obejmujący wszystkie istoty żywe: 'jestem, czyli posiadam cielesność, a więc reaguję na innych'. Mechanizm ten zawarty jest w Wielkim Układzie Życia (ang. Grand Design of Life) i Imperialnym Tetragonie Wcielenia (ang. Imperial Tetragon of Embodiment, zob. np. Puppel 2017).

Całość ziemskiego uniwersum komunikacyjnego (czy też 'uniwersalnej przestrzeni komunikacyjnej' - UPK, zob. Puppel 2004) stanowi globalny ekosystem językowo-komunikacyjny, którego ostatecznym celem jest pełna obsługa wszystkich istot żywych pomiędzy sobą (a więc komunikacja wewnątrzgatunkowa i ewentualna międzygatunkowa), a także swoista komunikacja tychże z nośnikiem ziemskim i Słońcem jako centrum większego układu planetarnego (np. fotosynteza), a więc 'mieszkaniem' dla wszystkich istot żywych (dom, gr. oikos), za pomocą dostępnych gatunkom i organizmom 'zasobów komunikacyjnych'. W sensie zasobów komunikacyjnych ziemskie uniwersum komunikacyjne stanowi o jego gatunkowym (istotowym) bogactwie wykształconym pracowicie w niezliczonych pokoleniach ziemskiego biosu.

Unikatowa istotowość człowieka, będąca w odniesieniu do stopnia złożoności w wyraźnej opozycji do istotowości innych gatunków, zasadza się na spionizowaniu postawy, uwolnieniu kończyn górnych, rozwoju języka (tj. jego wielopiętrowej struktury i uniwersalnych cech składających się na jego budowę, zob. np. Hockett 1960; Hockett 1963), jak i silnie rozbudowanej świadomości odnośnie do własnego gatunku, świadomości międzygatunkowej i nośnikowej wyrażonej w układzie 'kultury'. Idzie za tym równie unikatowa świadomość człowieka w odniesieniu do całokształtu życia na ziemi, zatem zdecydowanie unikatowa umiejętność objęcia całości i to w odniesieniu zarówno do różnorodności wszelkich zjawisk, jak i ich skali i trwania (metaświadomość). Jest więc człowiek nie tylko bezwzględnym eksploatatorem ziemskich zasobów, ale także mocą owej unikatowej i ewolucyjnie ustanowionej metaświadomości, niejako 'nadzorcą' całości. Jako nadzorca człowiek może zachowywać się jak ów benthamowski nadzorca więzienny funkcjonujący w idealnym panoptykonie (zob. Foucault), 
w którym ma pełen dostęp do całości ziemskiego habitatu i umieszczony w nim centralnie przygląda się bacznie wszystkiemu zarówno w charakterze bezwzględnego eksploatatora wszelkich zasobów ziemskich, jak też jako ich archiwizator i ewentualny obrońca.

W niniejszym eseju przedstawiam człowieka, posiadacza języka i gatunkowo najmłodszego uczestnika 'drzewa życia' (ang. tree of life) nie jako komunikatora, lecz jako tego, który może i powinien wystąpić w charakterze obrońcy istot bezjęzykowych celem zachowania bezcennej różnorodności komunikacyjnej charakteryzującej ziemski bios. Gatunkowo przebogata różnorodność 'przedludzkich systemów komunikacyjnych' (PSK) zawiera bowiem w sobie całe etologiczne bogactwo elementów, które w ten czy inny sposób, w tej czy innej skali, znalazły swoje miejsce w wytworzonym ewolucyjnie systemie językowo-komunikacyjnym człowieka vis-à-vis owych niezwykle bogatych przedludzkich systemów komunikacyjnych (zob. chociażby Darwin; Ruse). W tym sensie niniejsze krótkie opracowanie stanowi niewielki przyczynek omawiający mały fragment prowadzonych obecnie usilnych starań człowieka współczesnego w sprawie zachowania jak największej różnorodności wszelkich bytów na ziemi (bioróżnorodności), w tym zachowania różnorodności językowej (lingworóżnorodności, zob. Puppel 2007, 2019; Cardinale et al.; Eberhard et al.).

\section{Przedludzkie systemy komunikacyjne i ich starożytna różnorodność}

W systemie linneuszowskim (Linnaeus 1735), wspartym bogatymi nowożytnymi badaniami odnośnie do datowania poszczególnych gatunków (zob. np. Gould 1990; Gould 2002; dos Reis et al.), możemy przyjąć następujące (oczywiście bardzo przybliżone) przedziały czasowe dla ich istnienia:

- prokarioty (prokaryotes, wiek: 4-3 mld lat)

- pojawienie się fotosyntezy (wiek: 3,5 mld lat)

- eukarioty (eukaryotes, wiek: ok. 2 mld lat)

- bakterie (bacteria, wiek: 1 mld lat)

- pierwotniaki (protozoa, wiek: 1,5 mld lat)

- gąbki i grzyby (sponges i fungi, wiek: $800 \mathrm{mln}-700 \mathrm{mln}$ lat)

- koralowce (corals, wiek: ok. $700 \mathrm{mln}$ lat)

- ryby (fish, wiek: ok. 400 mln lat)

- rekiny (sharks, wiek: ok. 450 mln lat)

- czworonogi (tetrapods, wiek: ok. $400 \mathrm{mln}$ lat)

- owady (insects, wiek: ok. 400 mln lat)

- płazy (amphibians, wiek: ok. 300-250 mln lat) 
- gady i dinozaury (reptiles i dinosaurs, wiek: ok. 300 mln lat)

- ptaki (birds, wiek: ok. $100 \mathrm{mln}$ lat)

- ssaki (mammals, wiek: od ok. 65 mln lat do dziś)

- pszczoły (bees, wiek: ok. $100 \mathrm{mln}$ lat)

- naczelne (primates, wiek: ok. 100-65 mln lat)

- człowiek (Homo sapiens, wiek: ok. 300-200 tys. lat)

Przybliżone przedziały czasowe pokazuje także rysunek 1:



Rys. 1. Przedziały czasowe (w miliardach i milionach lat) reprezentujące historię życia na nośniku ziemskim

Źródło: Web. 01.12.2020. https://pixabay.com/images/search.

Jeśli na podstawie ogromnego dorobku paleobiologii (zob. np. Benton; Jablonski et al.; Briggs, Crowther) przyjmiemy za pewne wyodrębnienie tak bogatych podziałów życia na Ziemi i tak starożytne przedziały wiekowe pomiędzy poszczególnymi gatunkami, to logiczne jest założenie, że wszystkie one rozwinęły i nadal dysponują ustalonymi w tak długim okresie trwania gatunkowo adekwatnymi i udanymi systemami komunikacyjnymi, charakteryzującymi się nie 
tylko bogatą różnorodnością elementów dystynktywnych, ale także sprawdzonymi zachowaniami komunikacyjnymi zarówno w bieżącej komunikacji wewnątrzgatunkowej i międzygatunkowej, jak i w określonych środowiskach (np. wodnym i powietrznym).

Przedziały te w sposób jednoznaczny pokazują najpóźniejsze pojawienie się w obrębie biosu ziemskiego człowieka rozumnego, którego najważniejszymi wyznacznikami są, jak już wskazano powyżej, spionizowana postawa, wolne kończyny górne, język oparty na znakowości symbolicznej i rozwinięta w stopniu maksymalnym metaświadomość. To właśnie ona pozwala człowiekowi na zajęcie wygodnego miejsca $\mathrm{w}$ charakterze obserwatora $\mathrm{w}$ benthamowskim panoptykonie celem nie tylko dokonywania obserwacji, prognoz i opisów całego świata, ale także, w węższej perspektywie, badania i opisywania całego przedludzkiego uniwersum komunikacyjnego, a także rozważania możliwości jego archiwizowania i tym samym ocalania go wraz z jednoczesnym rzucaniem światła na ewolucję języka (Puppel 2020).

Przez wymienioną powyżej różnorodność przedludzkich systemów komunikacyjnych rozumie się występujące obecnie ogromne strukturalne bogactwo tychże ze wskazaniem dominujących trybów komunikacyjnych (łac. modus communicandi, ang. communication mode) i ich elementów strukturalnych. Poniżej podano wybrany zestaw trybów występujących w różnych przedludzkich systemach komunikacyjnych. Są to:

- słuchowy,

- wizualny,

- dotykowy,

- węchowy (w tym chemiczny),

- elektryczny,

- termiczny,

- sejsmiczny.

A oto krótkie opisy wymienionych trybów komunikacyjnych.

Tryb słuchowy charakteryzuje wszystkie istoty przedludzkie komunikujące się z otoczeniem za pomocą dźwięków (w tym ultradźwięków w przypadku szczurów), a więc: płazy (np. żaby), ptaki, ssaki (w tym ssaki wodne jak delfiny i wieloryby), naczelne.

Tryb wizualny charakteryzuje wszystkie istoty przedludzkie komunikujące się z otoczeniem za pomocą wzroku, a więc: ryby, rekiny, czworonogi, owady, płazy, gady, ptaki, ssaki, naczelne. Tryb wizualny, m.in. doskonale zilustrowany prezentacją ogona samca pawia w okresie godowym (rys. 2), jest, obok trybu węchowego, najpowszechniej stosowanym trybem komunikacyjnym w świecie istot przedludzkich. 


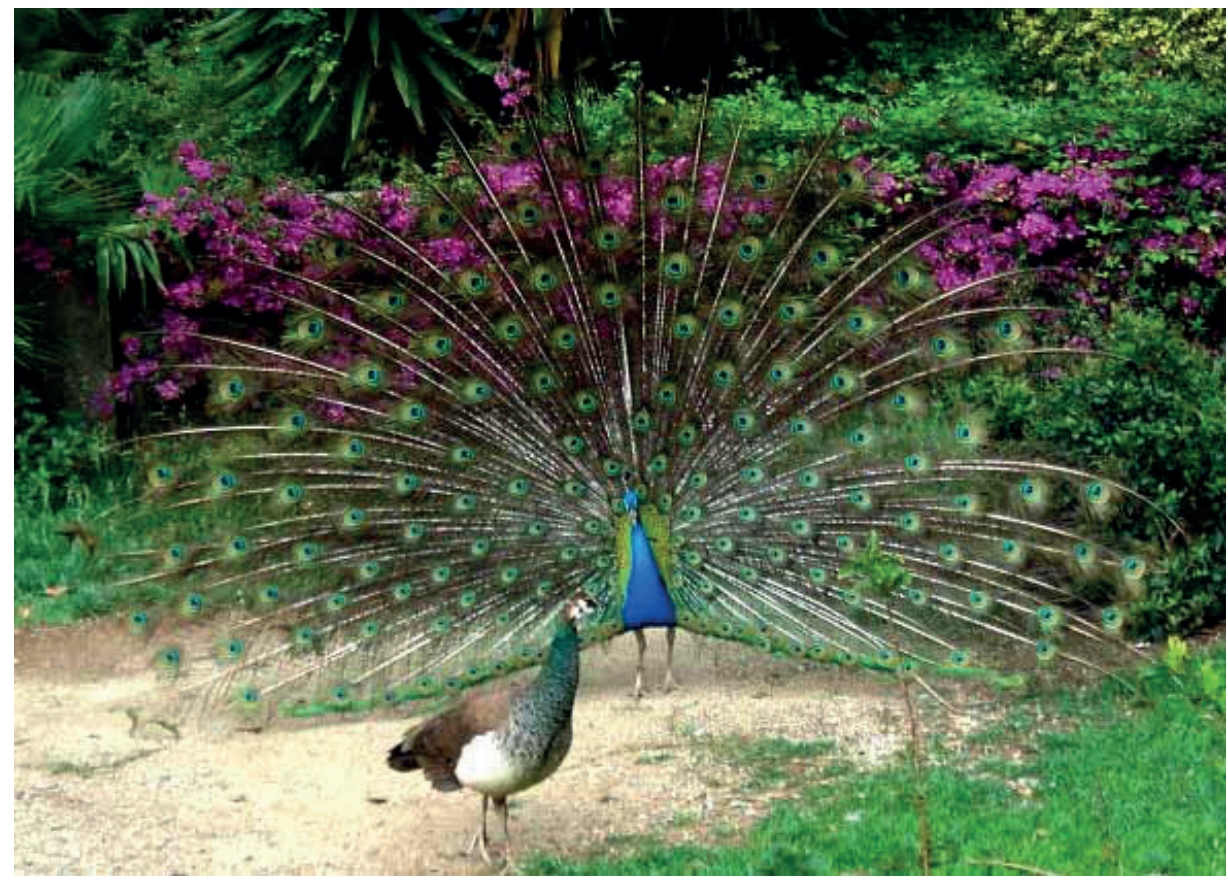

Rys. 2. Prezentacja ogona samca pawia (Pavo cristatus) w okresie godowym

Źródło: Web. 01.12.2020. http://www.ptakiozdobne.pl/21_Paw_krolewski.html\#galeria.

Tryb dotykowy charakteryzuje wszystkie istoty przedludzkie komunikujące się z otoczeniem za pomocą zmysłu dotyku, a więc: ryby, czworonogi, owady, płazy, gady, ptaki, ssaki, naczelne. Tryb dotykowy jest trzecim po wizualnym i węchowym najpowszechniej stosowanym trybem komunikacyjnym w świecie istot przedludzkich.

Tryb węchowy (w tym chemiczny) charakteryzuje wszystkie istoty przedludzkie komunikujące się z otoczeniem za pomocą zmysłu węchu, a więc: ryby, rekiny, czworonogi, owady (np. pszczoły), płazy, gady, ptaki, ssaki, naczelne. Tryb węchowy z użyciem feromonów, a więc mieszaniny różnych substancji chemicznych, które mają wywołać określoną reakcję organizmów należących do tego samego gatunku (zob. np. Stoka) jest, obok trybów wymienionych powyżej, kolejnym najpowszechniej stosowanym i być może najstarszym trybem komunikacyjnym w świecie istot przedludzkich (zob. np. Baeckens).

Tryb elektryczny charakteryzuje wszystkie istoty przedludzkie komunikujące się z otoczeniem za pomocą wytwarzania i odbierania pól elektrycznych, a więc ryby, płazy, gady i niektóre ssaki wodne, np. delfina gujańskiego, Sotalia guianensis (zob. np. Czech-Damal et al.). Tryb elektryczny występuje zatem bardzo rzadko, w większości ogranicza się do środowiska wodnego. 
Tryb termiczny charakteryzuje wszystkie istoty przedludzkie komunikujące się z otoczeniem za pomocą rozpoznawania promieniowania cieplnego wytwarzanego przez inne istoty. Dotyczy on np. wampira zwyczajnego, Desmodus rotundus (zob. np. Kishida et al.), czy pluskwiaków wysysających (zob. np. Campbell et al.), a zwłaszcza wielu węży, które mają zdolność do rozpoznawania takiego właśnie promieniowania (np. grzechotniki, Crotalus atrox) za pomocą nie tylko wzroku, ale także wgłębień znajdujących się w części twarzowej (ang. facial pits), zawierających wykrywacze temperatury i promieniowania podczerwonego (IR) (zob. np. Kardong i MacKessy; Gracheva et al.) oraz pozwalających na tworzenie odpowiednio precyzyjnych „wizerunków cieplnych” swoich ofiar, a także zachowanie dystansu do nich. W porównaniu z innymi trybami tryb termiczny jest unikatowy i wyraźnie ograniczony w odniesieniu do skali swojego występowania.

Tryb sejsmiczny charakteryzuje wszystkie istoty przedludzkie komunikujące się z otoczeniem za pomocą wykrywania różnego rodzaju drgań przekazywanych za pomocą takich przekaźników jak gleba, woda, łodygi roślin, liście trawy czy pajęczyna. Tryb ten rozwinęły m.in. żaby, krety, pszczoły, pająki, dżdżownice w odpowiedzi np. na swoisty „bębniący” typ lokomocji u czworonogów, wytwarzający wyczuwalne drgania nośnika ziemskiego i wywołujący określone reakcje istot umiejących je rozpoznać.

Tryby powyżej wymienione stanowią jako całość niezwykłe bogactwo komunikacyjne występujące na nośniku ziemskim. Ich obecność wskazuje na sprawdzone ewolucyjnie sposoby komunikowania się wewnątrz- i międzygatunkowe oraz z nośnikiem ziemskim w ogólnym celu utrzymania danego gatunku. Jak już zaznaczono powyżej, tryby te charakteryzują całe bogactwo przedludzkich systemów komunikacyjnych wykorzystujących pierwotną wskaźnikowość jako semiotyczną podstawę swojego istnienia. Mocno trzeba w tym miejscu podkreślić, że ich pełne poznanie, opisanie oraz staranna archiwizacja z pewnością pozwolą na pełniejsze poznanie i opisanie symbolicznej natury języka człowieka, opartego na wcześniej rozwiniętych systemach wskaźnikowych.

W tym kontekście trzeba wskazać na ewolucyjne ustalenie się u człowieka dla celów komunikacji wewnątrzgatunkowej trzech spośród wymienionych powyżej trybów, tj. słuchowego, wizualnego i dotykowego. Stworzyły one swoisty, gatunkowo ustanowiony, zespół słuchowo-twarzowo-dotykowy (zob. np. Puppel 2016), który znalazł się na wyposażeniu trzech porządków komunikacyjnych człowieka, tj. pierwotnego porządku słuchowo-ustnego, wprowadzonego znacznie później i wskutek przeniesienia się człowieka dodatkowo do stworzonego przez siebie wymiaru kulturowego porządku graficznego (pisanego i drukowanego) oraz będącego połączeniem obydwu porządku hybrydowego (zob. Puppel 2017). Dominację wyróżnionych przez człowieka trzech trybów w systemie komunikacji człowieka (SKC) ukazuje rysunek 3. 


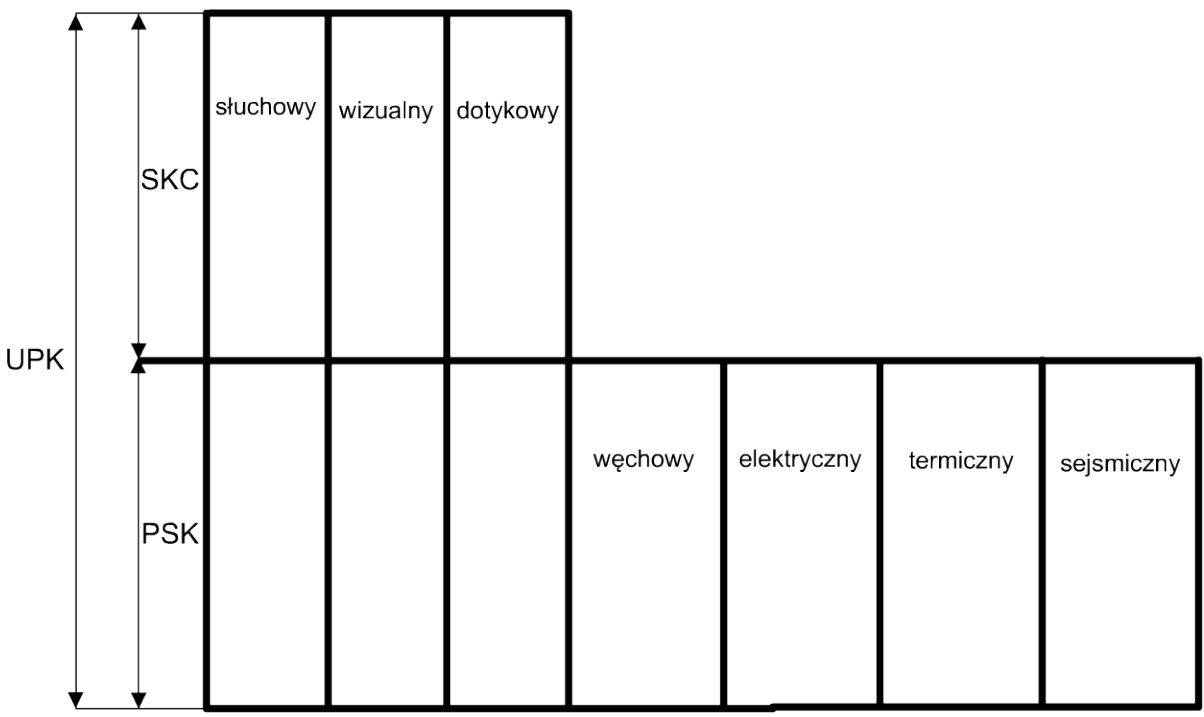

Rys. 3. Dominacja trybu słuchowego, wizualnego i dotykowego w systemie komunikacyjnym człowieka na tle innych trybów komunikacyjnych w przedludzkich systemach komunikacyjnych

UPK - uniwersalna przestrzeń komunikacyjna

PSK - przedludzkie systemy komunikacyjne

SKC - system komunikacyjny człowieka

Nie oznacza to, że inne spośród wymienionych powyżej trybów występujących w przedludzkich systemach komunikacyjnych nie odgrywają jakiejś (mniejszej lub większej) roli w komunikowaniu się człowieka wewnątrzgatunkowo czy z innymi (przedludzkimi) gatunkami. Zachowują one jednak u człowieka pierwotne zastosowanie wskaźnikowe, wyraźnie wspierające symboliczny język, wszelkie zachowania werbalne oraz reprezentują różnorodne uwarunkowania środowiskowe zachowania te określające. Ma to szczególne odniesienie do trybu węchowego, którego rola w kulturze została odpowiednio podkreślona (zob. np. Drobnick; Hoffmann; Ferdenzi et al.; także głośny film Pachnidło. Historia mordercy z roku 2006, oparty na powieści Patricka Süskinda z roku 1985 o tym samym tytule, który w szczególny sposób odniósł się do roli węchu i zapachu w kulturze Zachodu).

Zatem należy na koniec mocno podkreślić, że wymienione tryby komunikacyjne nie tylko doskonale ilustrują wciąż istniejącą bioróżnorodność i uczestnictwo tychże trybów w bogactwie zachowań komunikacyjnych w przedludzkich systemach komunikacyjnych, ale że właśnie z tego powodu należy dołożyć wszelkich starań, by lepiej je poznać i zachować w jak najpełniejszej formie. 


\section{Bibliografia}

Baeckens, Simon. „Evolution of animal chemical communication: insights from non-model species and phylogenetic comparative methods". Belgian Journal of Zoology, 149, 1, 2019, s. 63-93.

Benton, Michael J., red. The fossil record 2. London, Chapman and Hall, 1993.

Briggs, Derek E. G., Peter R. Crowther. Paleobiology II. Oxford, Blackwell Scientific Publications, 2001.

Campbell, Angela L. et al. „Biological infrared imaging and sensing”. Micron, 33, 2002, s. 211-225.

Cardinale, Bradley J. et al. „Biodiversity loss and its impact on humanity”. Nature, 486, 2012, s. 59-67.

Czech-Damal, Nicole U. et al. „Electroreception in the Guiana dolphin (Sotalia guianensis)”. Proceedings of the Royal Society B, 279, 2012, s. 663-668.

Darwin, Charles. The expression of the emotions in man and animals. London, John Murray, $1872 / 1892$.

Drobnick, Jim, red. The smell culture reader. Oxford, Berg Publishers, 2006.

Eberhard, David M., Gary F. Simons, Charles D. Fennig, red. Ethnologue: languages of the world. 22 ed. Dallas, TX, SIL International, 2019.

Ferdenzi, Camille et al. „Idividual differences in verbal and non-verbal affective responses to smells: Influence of odor label across cultures". Chemical Senses, 42, 2017, s. 37-46.

Foucault, Michel. Discipline and punishment: The birth of the prison. New York, Vintage Books, 1977.

Gould, Stephen J. The structure of evolutionary theory. Cambridge (Mass.), Harvard University Press, 2002.

Gould, Stephen J. Wonderful life: The Burgess Shale and the nature of history. New York, W.W. Norton, 1990.

Gracheva, Elena et. al. „Molecular basis of infrared detection by snakes”. Nature, 464, 2010, s. 1006-1011.

Hauser, Marc D. The evolution of communication. Cambridge (Mass.), The MIT Press, 1997.

Hockett, Charles F. „The origin of speech”. Scientific American, 20, 1960, s. 89-96.

Hockett, Charles F. „The problem of universals in language”. Universals of language. Red. Joseph H. Greenberg. Cambridge (Mass.), The MIT Press, 1963/1966, s. 1-29.

Hoffmann, Beata. Perfumy. Uwarunkowania kulturowo-społeczne. Kraków, Oficyna Wydawnicza Impuls, 2013.

Jablonski, David, Douglas H. Erwin, Jere H. Lipps, red. Evolutionary paleobiology. Chicago, The University of Chicago Press, 1996.

Kardong, Kenneth V., Stephen P. MacKessy. „The strike behavior of a congenitally blind rattlesnake". Journal of Herpentology, 25, 2, 1991, s. 208-211.

Kishida, Ryo et al. „A suspected infrared-recipient nucleus in the brainstem of the vampire bat, Desmodus rotundus". Brain Research, 322, 1984, s. 351-355.

Linnaeus, Carl. Systema naturae sive regna tria naturae systematice proposita per classes, ordines, genera, \& species. Lund, Haak, T. i J.W. de Groot, 1735.

Nöth, Winfried. Handbook of semiotics. Bloomington (IN), Indiana University Press, 1995.

Puppel, Joanna. „Wskaźnikowość twarzy ludzkiej: krótki przegląd problematyki”. Scripta Neophilologica Posnaniensia, 16, 2016, s. 201-206. 
Puppel, Stanisław. „ECOLI[S]: essays and notes on ecolinguistic synergy and synthesis”. Scripta de Communicatione Posnaniensi. Seria: Prace Naukowe Katedry Ekokomunikacji UAM. T. 8. Poznań, Zakład Graficzny UAM, 2017.

Puppel, Stanisław, red. Ochrona języków naturalnych. Scripta de Communicatione Posnaniensi. Seria: Materiały Dydaktyczne Katedry Ekokomunikacji UAM. T. 1. Poznań, Zakład Graficzny UAM, 2007.

Puppel, Stanisław. „An outline of a domain-resource-agent-access-management (DRAAM) model of human communication: towards an ecology of human communication". Electronic Journal Oikeios Logos, 1, 2004, s. 1-26.

Puppel, Stanisław. „Uwagi w sprawie zachowania lingworóżnorodności w kontekście bioróżnorodności”. Humanistica, 21, 2019, s. 59-71.

Puppel, Stanisław, red. A bibliography of writings on the origins and evolution of language and communication. A tribute to science (evolving). Poznań [w druku].

dos Reis, Mario, Philip C. J. Donoghue, Ziheng Yang. „Bayesian molecular clock dating of species divergences in the genomics era". Nature Reviews Genetics, 8, 2015, s. 1-12. DOI: 10.1038/ nrg.2015.8.

Ruse, Michael, red. The Oxford handbook of philosophy of biology. Oxford, Oxford University Press, 2008.

Sebeok, Thomas A. Perspectives in zoosemiotics. The Hague, Mouton, 1972.

Stoka, Angel M. „Phylogeny and evolution of chemical communication: an endoctrine approach”. Journal of Molecular Endocrinology, 22, 1999, s. 207-225.

Süskind, Patrick. Pachnidło. Historia pewnego mordercy. Przeł. Małgorzata Łukasiewicz. Warszawa, Świat Książki, 1990.

Süskind, Patrick. Das parfum. Die Geschichte eines Mörders. Zürich, Diogenes Verlag, 1985. 